
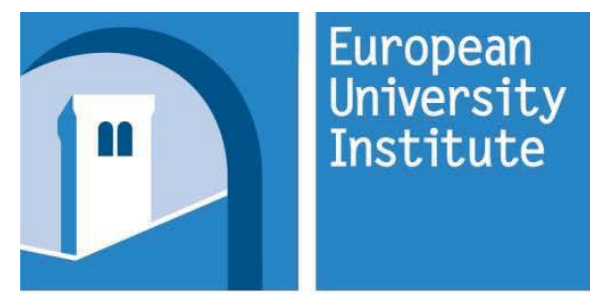

ROBERT

SCHUMAN

CENTRE FOR

ADVANCED

STUDIES
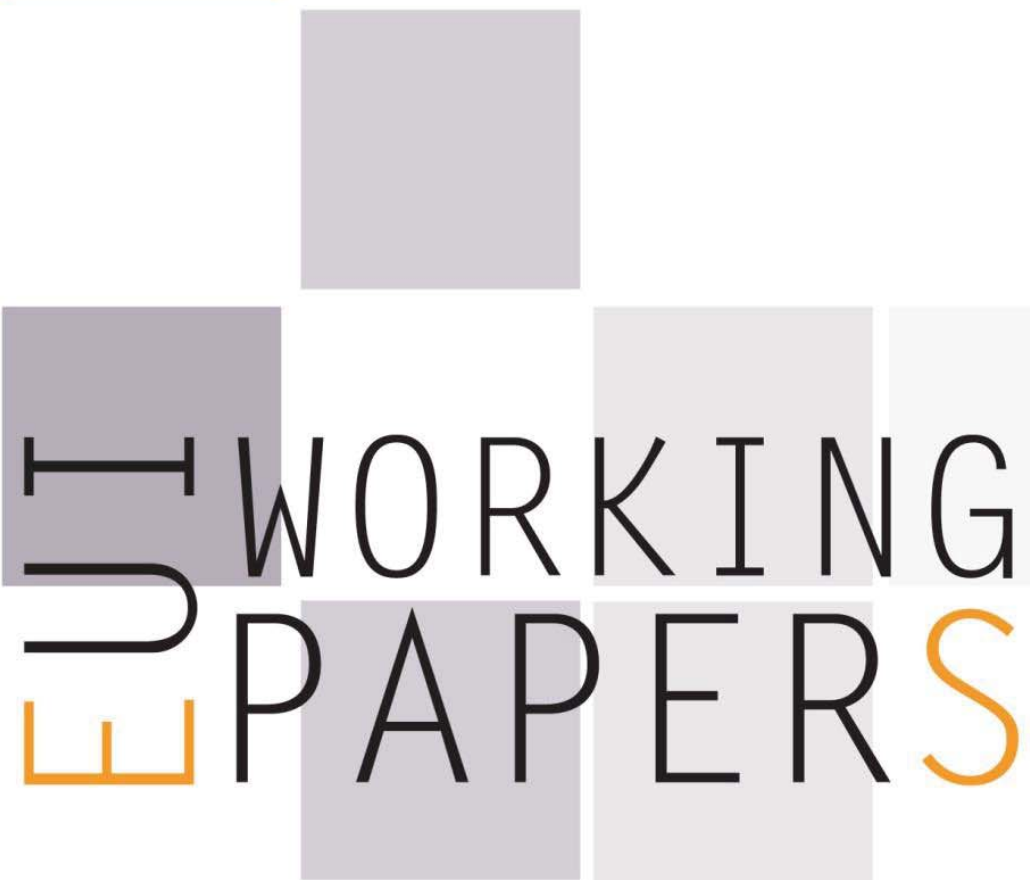

RSCAS 2015/85

Robert Schuman Centre for Advanced Studies Global Governance Programme-200

Regional Trade Agreements and Trade Costs in Services

Sébastien Miroudot and Ben Shepherd 

European University Institute

Robert Schuman Centre for Advanced Studies

Global Governance Programme

Regional Trade Agreements and Trade Costs in Services

Sébastien Miroudot and Ben Shepherd

EUI Working Paper RSCAS 2015/85 
This text may be downloaded only for personal research purposes. Additional reproduction for other purposes, whether in hard copies or electronically, requires the consent of the author(s), editor(s). If cited or quoted, reference should be made to the full name of the author(s), editor(s), the title, the working paper, or other series, the year and the publisher.

ISSN 1028-3625

(c) Sébastien Miroudot and Ben Shepherd, 2015

Printed in Italy, November 2015

European University Institute

Badia Fiesolana

I - 50014 San Domenico di Fiesole (FI)

Italy

www.eui.eu/RSCAS/Publications/

www.eui.eu

cadmus.eui.eu 


\section{Robert Schuman Centre for Advanced Studies}

The Robert Schuman Centre for Advanced Studies (RSCAS), created in 1992 and directed by Professor Brigid Laffan, aims to develop inter-disciplinary and comparative research on the major issues facing the process of European integration, European societies and Europe's place in $21^{\text {st }}$ century global politics.

The Centre is home to a large post-doctoral programme and hosts major research programmes, projects and data sets, in addition to a range of working groups and ad hoc initiatives. The research agenda is organised around a set of core themes and is continuously evolving, reflecting the changing agenda of European integration, the expanding membership of the European Union, developments in Europe's neighbourhood and the wider world.

Details of the research of the Centre can be found on: http://www.eui.eu/RSCAS/Research/

Research publications take the form of Working Papers, Policy Papers, and e-books. Most of these are also available on the RSCAS website:

http://www.eui.eu/RSCAS/Publications/

The EUI and the RSCAS are not responsible for the opinions expressed by the author(s).

\section{The Global Governance Programme at the EUI}

The Global Governance Programme is one of the flagship programmes of the Robert Schuman Centre for Advanced Studies at the European University Institute (EUI). It aims to: build a community of outstanding professors and scholars, produce high quality research and, engage with the world of practice through policy dialogue. At the Global Governance Programme, established and early career scholars research, write on and discuss, within and beyond academia, issues of global governance, focussing on four broad and interdisciplinary areas: European, Transnational and Global Governance; Global Economics; Europe in the World; and Cultural Pluralism.

The Programme also aims to contribute to the fostering of present and future generations of policy and decision makers through its unique executive training programme, the Academy of Global Governance, where theory and "real world" experience meet. At the Academy, executives, policy makers, diplomats, officials, private sector professionals and academics, have the opportunity to meet, share views and debate with leading academics, top-level officials, heads of international organisations and senior executives, on topical issues relating to governance.

For more information: http://globalgovernanceprogramme.eui.eu 



\title{
Regional Trade Agreements and Trade Costs in Services
}

\author{
Sébastien Miroudot and Ben Shepherd*
}

October 28, 2015

\begin{abstract}
This paper analyses the relationship between regional trade integration and trade costs in services industries. The empirical analysis relies, on the one hand, on a dataset of theory-consistent bilateral trade costs calculated for 61 countries over the period 2000-2011 and, on the other hand, on an analysis of services commitments in 66 regional trade agreements to which these countries are parties. Despite the proliferation of services RTAs in the past decade, we do not find significantly lower bilateral trade costs among countries having signed such agreements. Several possible explanations are discussed. First, the gaps in services trade data and the difficulty to account for all modes of supply could influence our results. Second, the nature of services trade liberalisation makes it difficult to discriminate between domestic and foreign service providers (thus not impacting the relative costs they face). Third, there is no clear evidence that countries signing services RTAs do intend to create actual preferences for companies in partner countries. Services RTAs are about preferential "bindings". Regionalism in the case of services seems non-discriminatory and does not lead to trade preferences.
\end{abstract}

JEL Codes: F13; F15.

Keywords: Trade policy; Trade in services; Regional trade agreements; services trade liberalisation.

${ }^{*}$ S. Miroudot: corresponding author, Senior trade policy analyst, OECD, sebastien.miroudot@ oecd.org. B. Shepherd: Principal, Developing Trade Consultants, ben@developing-trade.com. The authors are writing in a strictly personal capacity. The views expressed are theirs only, and do not reflect in any way those of the OECD Secretariat or the member countries of the OECD. The authors are grateful to the Groupe d'Economie Mondiale at Sciences Po for supporting this research, and to Patrick A. Messerlin for many helpful discussions and comments. The analysis of services commitments in regional trade agreements was carried out with the help of Jehan Sauvage and Marie Sudreau. 


\section{Introduction}

There are several motives for negotiating regional trade agreements (RTAs) ${ }^{1}$ and not all of them are based on economic considerations (WTO, 2011). However, it seems straightforward that when signing an RTA, countries aim at reducing trade barriers among themselves. Preambles of trade agreements generally emphasize the promotion of trade and the removal of trade distortions as objectives that motivate the disciplines of the agreement. We should therefore expect RTAs to decrease trade costs between their parties, and empirical work in the case of goods tends to support this idea (see for example Pomfret and Sourdin, 2009; Chauffour and Maur, 2011 and WTO, 2011for a review).

Regional trade agreements covering services have not proliferated as much as those covering goods. There were 88 agreements notified to WTO under the General Agreement on Trade in Services (GATS) at the end of August 2011, as compared to 213 notified under the General Agreement on Tariffs and Trade (GATT). While fewer RTAs deal with services, the share of world trade covered by these agreements is higher for services than for goods. As will be discussed in the paper, one should not interpret the fact that two countries have an RTA in services as a sign of "preferential" trade. In the case of goods, only 16 percent of world trade can be regarded as preferential, i.e. actually benefitting from a lower tariff in the context of the RTA (WTO, 2011). The same can be expected from services as GATS-plus commitments are legal bindings that do not guarantee preferential treatment.

Recently signed RTAs are generally characterized as "deep integration" because they go beyond traditional market access concerns and deal with a broad range of trade-related issues. They also deal more with "behind-the-border" policies and address domestic regulations that have an impact on trade. Services is somehow a "borderline" area. Part of services commitments in RTAs is stricly speaking about "market access". But as barriers to trade in services are mainly "behind-the-border",

\footnotetext{
${ }^{1}$ A note on terminology: we refer to "regional trade agreements" rather than "preferential trade agreements" or "free trade agreements", as the expression seems to us more neutral. Of course, it could be pointed out that most agreements are "bilateral" rather than "regional". But trade agreements in the case of services are not always "preferential" and never lead to "free trade". Switching to PTAs or FTAs does not improve the accuracy of the terminology.
} 
services also illustrate the "deep integration" disciplines in recent RTAs.

Moreover, there is a consensus in the literature on the fact that services RTAs are WTO-plus. Several studies have compared market access and national treatment commitments in GATS and commitments in RTAs and unequivocally found that the latter cover a much higher number of subsectors than the former (Marchetti and Roy, 2008; Fink and Molinuevo, 2008; Miroudot et al., $2010)^{2}$. But commitments are legal bindings and do not always correspond to the actual trade regime, which might be more liberal (or less liberal). The extent to which services RTAs have led to trade liberalisation and actually reduced trade costs becomes an empirical question.

Building on Miroudot et al. (2012) where we have developed theory-consistent estimates of bilateral trade costs for a large number of countries over the period 1999-2009 (and which we extend to 2011 here), this chapter further analyses the relationship between regional integration and the evolution of trade costs in services industries. The next section explains how we measure trade costs in services and describes the database of services commitments in RTAs that we use in the analysis. Section 3 provides stylised facts on trade costs within and outside regional trade agreements and Section 4 discusses why services RTAs seem to have a limited impact on trade costs in services. Section 5 concludes.

\footnotetext{
${ }^{2}$ Some studies have also uncovered the phenomenon of GATS-minus commitments. See Adlung and Miroudot (2012).
} 


\section{Empirical data on trade costs and services trade liberalisa- tion at the regional level}

\subsection{Bilateral trade costs in services: a database covering 61 countries over the period 2000-2011}

Starting from the standard, theory-consistent gravity model of Anderson and van Wincoop (2003), Novy (2011) develops a comprehensive measure of bilateral trade costs. ${ }^{3}$ Equation 1 presents that measure in ad valorem equivalent terms as $\tau_{i j k t}$, where $k$ indexes sectors and $t$ indexes time. It is the geometric average of bilateral trade costs for exports from country $i$ to country $j$ and from country $j$ to country $i$, expressed relative to domestic trade costs in each country ( $\frac{t_{i j}}{t_{i i}}$ and $\frac{t_{j i}}{t_{j j}}$ respectively). To calculate it, all that is required is data on domestic production relative to nominal exports in both countries $\left(\frac{x_{i i}}{x_{i j}}\right.$ and $\frac{x_{j j}}{x_{j i}}$ respectively). The parameter $\sigma$ is the elasticity of substitution among varieties in a sector, assuming the Anderson and Van Wincoop-based derivation of Novy's measure of trade costs.

$$
\tau_{i j k t}=\left(\frac{t_{i j k t} \cdot t_{j i k t}}{t_{i i k t} \cdot t_{j j k t}}\right)^{\frac{1}{2}}-1=\left(\frac{x_{i i k t} \cdot x_{j j k t}}{x_{i j k t} \cdot x_{j i k t}}\right)^{\frac{1}{2(\sigma-1)}}-1
$$

Intuitively, Novy's measure captures the fact that if a country's trade costs vis-à-vis its trading partners fall, then a part of its production that was previously consumed domestically will instead be shipped overseas. Trade costs are thus closely related to the extent to which a country trades with itself rather than other countries, and data on this kind of relative openness can be used to track the level of trade costs and their variation over time. Importantly, this measure of trade costs is "top down" rather than "bottom up". By this we mean that it infers the ratio of inter- to intranational trade costs based on observed patterns of production and trade around the world, rather than building up an estimate of trade costs based on data covering particular types of impediments

\footnotetext{
${ }^{3}$ In fact, Novy (2011) shows that basically the same measure can be derived from a wide variety of theoretical models of international trade, including Chaney (2008) and Eaton and Kortum (2002). The interpretation of some parameters changes depending on the model used, but the overall approach remains very similar. Novy's approach builds on Head and Ries (2001).
} 
to trade. It thus takes account of all factors that influence trade costs, and is not subject to the kind of omitted variables bias that calls into question the results of previous attempts to measure trade costs in services by analyzing the results of gravity model estimates (e.g., Walsh, 2006).

We use this approach to calculate new trade costs measures for 61 countries and nine broadly defined industries (including four for services) over the period 2000-2011. Our measure of trade costs captures the costs associated with "pure" cross-border services trade under Modes 1, 2 and 4 of the General Agreement on Trade in Services (GATS). We do not extend the analysis to sales by foreign affiliates (GATS Mode 3) due to lack of data. ${ }^{4}$ For sectoral output and exports, we rely on the information provided in the OECD Inter-Country Input-Output tables that are constructed for the OECD-WTO Trade in Value Added (TiVA) database. ${ }^{5}$ These data are already harmonized and made comparable across countries. They are sourced from national accounts but reconciled with trade statistics in a global accounting framework. For data on trade in goods, we rely on the OECD's ITCS database which provides data on bilateral trade flows directly in the ISIC Rev.3 format. Things are more complicated for services where the coverage of official statistics is generally weak and data are not always available at the bilateral level by industry. We also rely on the work done by the OECD and the WTO in the context of the TiVA database, using a set of harmonized data from the OECD's TISP database (International Trade in Services by Partner Country), Eurostat's balance of payments statistics and the UN's Service Trade database. This dataset includes various estimates and all data are converted from the EBOPS classification to ISIC Rev. 3 using a concordance. ${ }^{6}$ In line with Novy (2011), we assume $\sigma=8$ throughout, but our results are robust to alternative assumptions.

By way of introduction to the trade costs data, Figure 1 presents average figures for the period 20002011. The data are disaggregated by sector and trade-weighted tariff equivalents are calculated.

\footnotetext{
${ }^{4}$ In Section 4, we report results for sales of foreign affiliates based on a small sample of countries for which data are available. We also indicate how bilateral "Mode 3 trade costs" could be calculated with an approach similar to Novy (2011).

${ }^{5}$ We have both gross output and exports at the industry level in this set of I-O tables, the two variables needed to calculate domestic trade.

${ }^{6}$ See Spinelli and Miroudot (2015) for detailed information on the creation of these services trade statistics.
} 
Figure 1: Average trade costs in services sectors, tariff equivalent

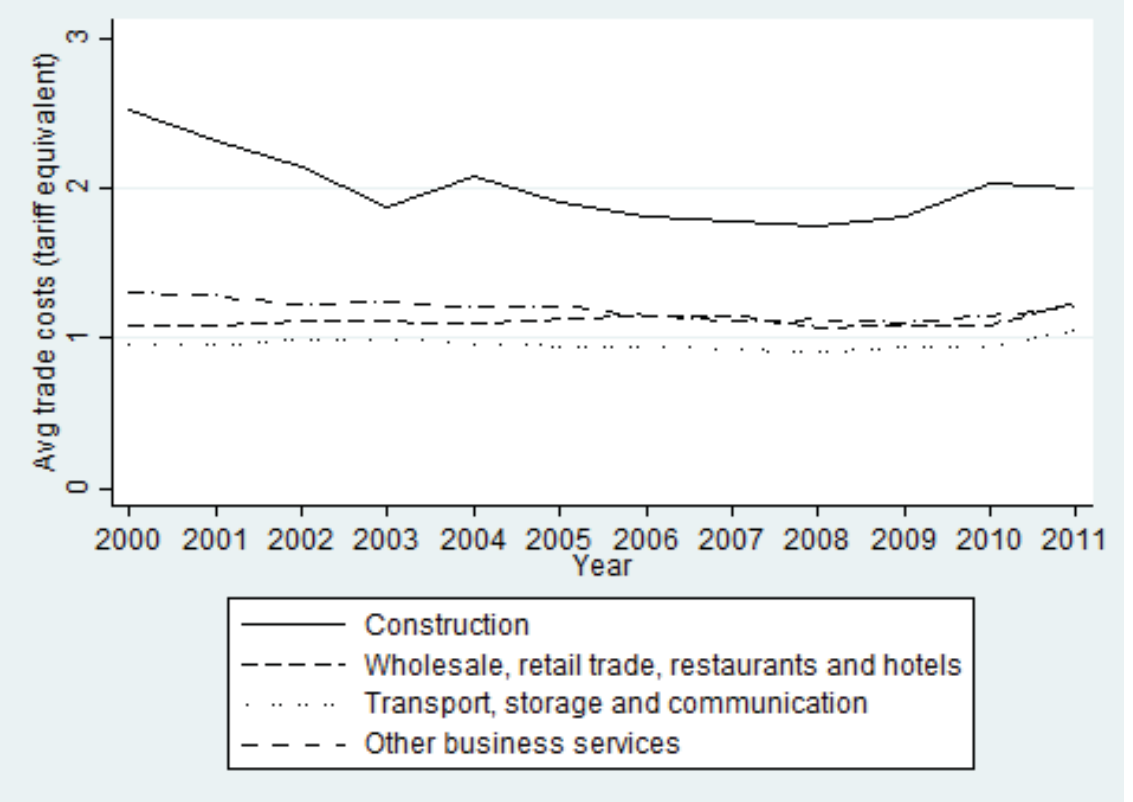

Trade costs are very high for the construction industry (keeping in mind that only cross-border flows corresponding to short-term construction projects are accounted for in BOP statistics) while a convergence is observed in the case of other services industries with still significantly high trade costs around $100 \%$ when expressed as a tariff equivalent. There if a trend towards declining trade costs between 2000 and 2008 but services trade costs are then raising after the crisis.

\subsection{Services commitments in 66 regional trade agreements}

To assess the impact of RTAs on trade costs, we use a database developed at the OECD that covers all services agreements where an OECD economy, China, or India is a party (Miroudot et al., 2010). This accounts for 66 of the 88 agreements notified to WTO under GATS Art. V (as of August 2011). ${ }^{7}$ The database reports market access and national treatment commitments in the 155 sub-sectors of the GATS Services Sectoral Classification List. Horizontal restrictions - those that apply to all subsectors - are also taken into account and reported on all subsectors. The information is provided for each signatory of the RTA by mode of supply.

\footnotetext{
${ }^{7}$ The full list of RTAs included is given in Annex 1 .
} 
Table 1: Typology of limitations in partial market access and national treatment commitments

\begin{tabular}{|c|c|c|c|}
\hline \multirow{2}{*}{\multicolumn{2}{|c|}{$\begin{array}{l}\text { Category } \\
\text { Market access }\end{array}$}} & Mode of supply & \multirow[t]{2}{*}{ Examples } \\
\hline & access & & \\
\hline MA1 & $\begin{array}{l}\text { Scope of sub-sector limited (as compared to W/120 } \\
\text { classification) }\end{array}$ & All & $\begin{array}{l}\text { Commitment limited to a list of activties. } \\
\text { Commitment in sub-sector } x \text { but not including } y \text {. }\end{array}$ \\
\hline MA2 & Restrictions on foreign ownership or on the type of & Mode 3 & Foreign equity limits \\
\hline & & & $\begin{array}{l}\text { Only joint ventures are allowed } \\
\text { Restrictions on mergers and acquisitions for foreign firms }\end{array}$ \\
\hline MA3 & Quantitative restrictions on the service or service & Mode $1,2 \& 3$ & $\begin{array}{l}\text { Limitations on the number of service suppliers (e.g., quota or economic need test) } \\
\text { Limitations on the total value of transaction or assets } \\
\text { Limitations on the quantity of service output }\end{array}$ \\
\hline MA4 & Market access restrictions to the movement of people & Mode 4 & $\begin{array}{l}\text { Limitations on the number of natural persons } \\
\text { Nationality requirements for suppliers of services }\end{array}$ \\
\hline \multicolumn{4}{|c|}{ National treatment } \\
\hline NT1 & $\begin{array}{l}\text { Nationality and residency requirements for boards of directors and } \\
\text { managers, discriminatory licensing requirements }\end{array}$ & Mode $1 \& 3$ & $\begin{array}{l}\text { Nationality and residency requirements for boards of directors and managers } \\
\text { Discriminatory licensing requirements }\end{array}$ \\
\hline NT2 & National treatment restrictions to the movement of people & Mode 4 & Discriminatory qualification or licensing requirements \\
\hline NT3 & Discriminatory measures with regard to subsidies or taxes & Mode $1,2 \& 3$ & $\begin{array}{l}\text { Eligibility to subsidies resened for nationals } \\
\text { A tax is imposed on non-residents }\end{array}$ \\
\hline NT4 & Restrictions on ownership of property/land & Mode $1,2 \& 3$ & $\begin{array}{l}\text { Foreigners may not acquire direct ownership of land } \\
\text { Non-residents are excluded from the acquisition of real estate }\end{array}$ \\
\hline NT5 & Other discriminatory mea sures & Mode $1,2 \& 3$ & $\begin{array}{l}\text { Discriminatory measures with respect to competition } \\
\text { Prohibition on the hire of local professionals } \\
\text { Local content requirements } \\
\text { Technology transferitraining requirements }\end{array}$ \\
\hline
\end{tabular}

Commitments are either "full" (no limitation), "partial" (some limitations listed), or "unbound" (no commitment). In addition, "partial" commitments are broken down into nine different types of trade restrictive measures, four for market access and five for national treatment. This classification of non-conforming measures is detailed in Table 1. The database includes similar analysis for commitments in GATS and can be used to assess to what extent RTAs are WTO-plus and provide for additional commitments.

As this database is of a qualitative nature, we compute indices that capture the extent to which services RTAs are preferential as compared to the GATS. The methodology is the following. An initial score of 100 is assigned to each agreement, country, subsector, and mode of supply regardless of its degree of commitment (including the GATS). Then, depending on whether the subsector is "full", "unbound", or subject to some restrictions ("partial"), some points are deducted from this amount. The precise number of points granted to each restriction relies on a few assumptions:

- Market access matters relatively more than national treatment.

- Unbound is worse than partial, which is in turn worse than full. 
- Quantitative restrictions such as quotas or licensing requirements are more trade-restrictive than discrimination on subsidies or prohibitions on partnerships for instance.

There is some inherent subjectivity in ranking and weighting the importance of trade restrictive measures and it is beyond the scope of this chapter to discuss how it can be done. Table 2 summarizes our own subjective assessment and details the scores for each mode of supply (the points that are lost out of a total of 100 when the sub-sector is unbound or partial). We note that no commitment at all (unbound) does not give a score of zero for a given sub-sector and mode of supply but 20 (out of 100). "Unbound" means that there is no commitment in the RTA to provide market access and national treatment, but this should not be understood as trade being banned. It could be the case that no restrictive measure is actually in place in the country.

Table 2: Scores used to calculate the RTA indexes

\begin{tabular}{|c|c|c|c|c|c|c|c|c|c|c|c|c|c|}
\hline \multirow{2}{*}{ Mode } & \multicolumn{6}{|c|}{ Market access } & \multicolumn{7}{|c|}{ National treatment } \\
\hline & Unbound & MA1 & MA2 & MA3 & MA4 & Full & Unbound & NT1 & NT2 & NT3 & NT4 & NT5 & Full \\
\hline Mode 1 & 50 & 15 & 0 & 20 & 0 & 0 & 30 & 15 & 0 & 2.5 & 2.5 & 2.5 & 0 \\
\hline Mode 2 & 50 & 20 & 0 & 0 & 0 & 0 & 30 & 0 & 0 & 5 & 5 & 5 & 0 \\
\hline Mode 3 & 50 & 15 & 20 & 5 & 0 & 0 & 30 & 15 & 0 & 2.5 & 2.5 & 2.5 & 0 \\
\hline Mode 4 & 50 & 15 & 0 & 0 & 20 & 0 & 30 & 0 & 15 & 0 & 0 & 0 & 0 \\
\hline
\end{tabular}

Since we work with data on cross-border trade in services, we assign Mode 1 a much larger weight (70\%) than is the case for the other modes (10\% for each). Yet, we choose not to give a zeroweight to Modes 3 and 4 to account for the potential complementarities that may exist between modes of supply. Mode 2 is also part of cross-border trade but is economically less important and rather difficult to restrict. We are now left with a score ranging between 0 and 100 for each agreement/country/subsector. The next step is then to compute for each RTA the difference between the agreement's score and the GATS score. This difference therefore takes on values from -100 to 100. Because an agreement that is worse than GATS (i.e., a GATS minus) is de facto ineffective, we replace all negative values by zeros, which means no preferential treatment at all. Hence, the higher the value of the index, the more preferential the RTA for a given country/subsector. 
Last, we convert W/120 subsectors into ISIC Rev.3 sectors using the UN's Provisional Central Product Classification as an intermediate correspondence. Since W/120 subsectors and ISIC Rev. 3 sectors do not match one-to-one, we averaged the RTA index when needed using equal weights. Eventually, we get an index of the preferential content of RTAs for each party to an agreement that is compatible with our trade costs data at the sector level.

\section{Trade costs and regional trade agreements}

\subsection{Stylized facts}

Our dataset provides bilateral trade costs at the industry level. To compare the average trade costs within and outside RTAs, we use a trade-weighted average across countries. Trade costs for goods within RTAs are the average bilateral trade costs in manufacturing industries of countries that are party to an RTA covering goods. Trade costs for services are measured within RTAs that have provisions on services (a smaller subset of the RTAs covering goods). In addition, we keep only pairs of countries for which we have consistent data over time (between 2000 and 2011). Figure 2 highlights the important difference between goods trade and services trade when it comes to the role of RTAs. On the left, we see that in the case of goods, trade costs are significantly lower within RTAs. The difference tends to narrow over time but trade costs in 2011 are still 22\% lower within RTAs. For services, trade costs are on average higher than for goods. Tariff equivalents, whether within or outside RTAs, are always between 100 and 125 percent. Moreover, there is no major difference between trade costs measured within RTAs and between countries that are not part of a services trade agreement. In 2011, trade costs for services are on average 10 percent lower within RTAs. Goods RTAs are therefore associated with a difference in trade costs of about twice as much as services RTAs.

The increase in trade costs over the period (both for goods and services) is partly a composition effect. The group of countries with an RTA at the end of the period is made up of RTAs with 
Figure 2: Trade costs within and outside RTAs: goods versus services
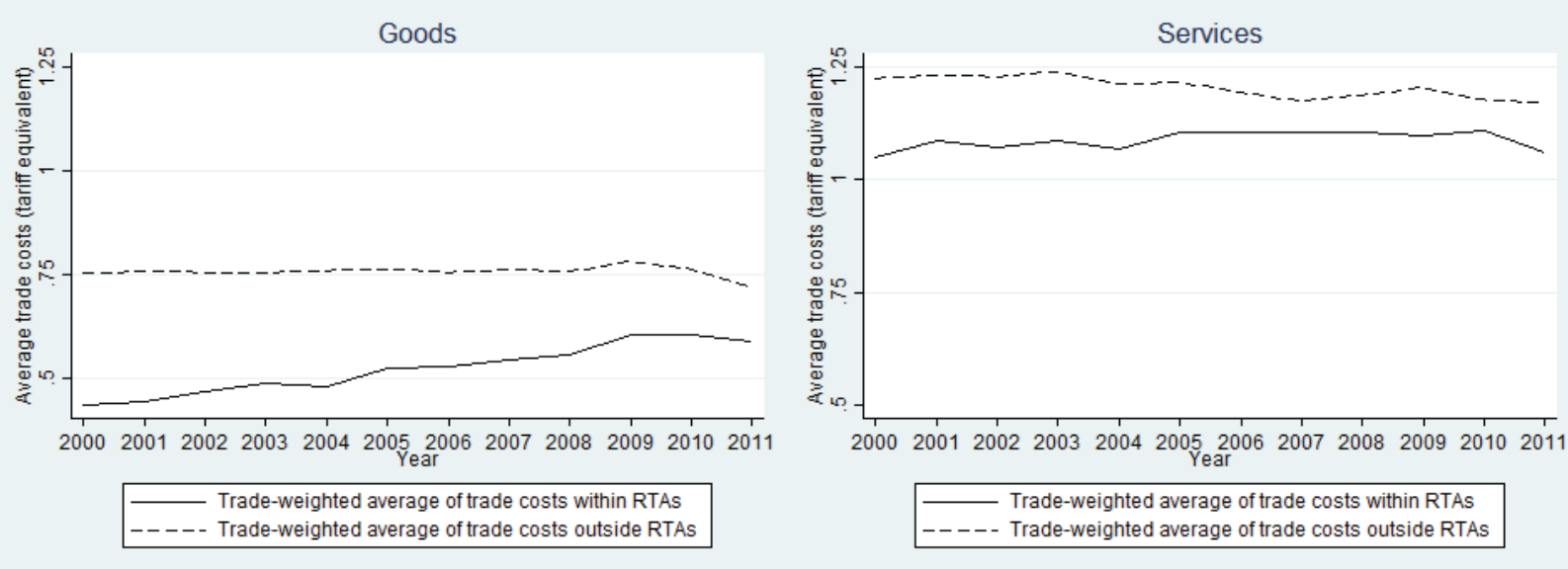

a relatively higher level of trade costs. One could explain this by the fact that countries initially signed RTAs with their main trading partners that are closer in a geographic sense but also culturally or institutionally. It is therefore not surprising to see a decrease in the discrepancy between trade costs within and outside RTAs. But the results for services suggest that services agreements are of a different nature as compared to goods agreements.

To further assess to what extent Figure 2 reflects the composition of the group of countries having signed an RTA or the evolution of trade costs within these RTAs, Figure 3 gives an average bilateral trade cost before and after the entry into force of the RTA. We set to $t=0$ the year of entry into force of each agreement and we report the average trade costs (over all the RTAs) up to five years before and after this date. As trade costs are to some extent cyclical and vary over time, pulling different years together introduces some volatility but the results suggest that both in the case of goods and services, RTAs contribute to a decrease in trade costs. Of course, these descriptive data do not say anything about causality but they suggest that Figure 2 captures more of a composition effect.

Lastly, we present in Figure 4 results for the European Union. We have separately calculated average bilateral trade costs among EU Members and in EU RTAs (i.e. between EU Members and countries with which the EU has signed an RTA). We have also included in the Figure the average trade costs for non-EU RTAs (i.e. other RTAs where EU countries are not parties). The 
Figure 3: Trade costs before and after the entry into force of the RTA

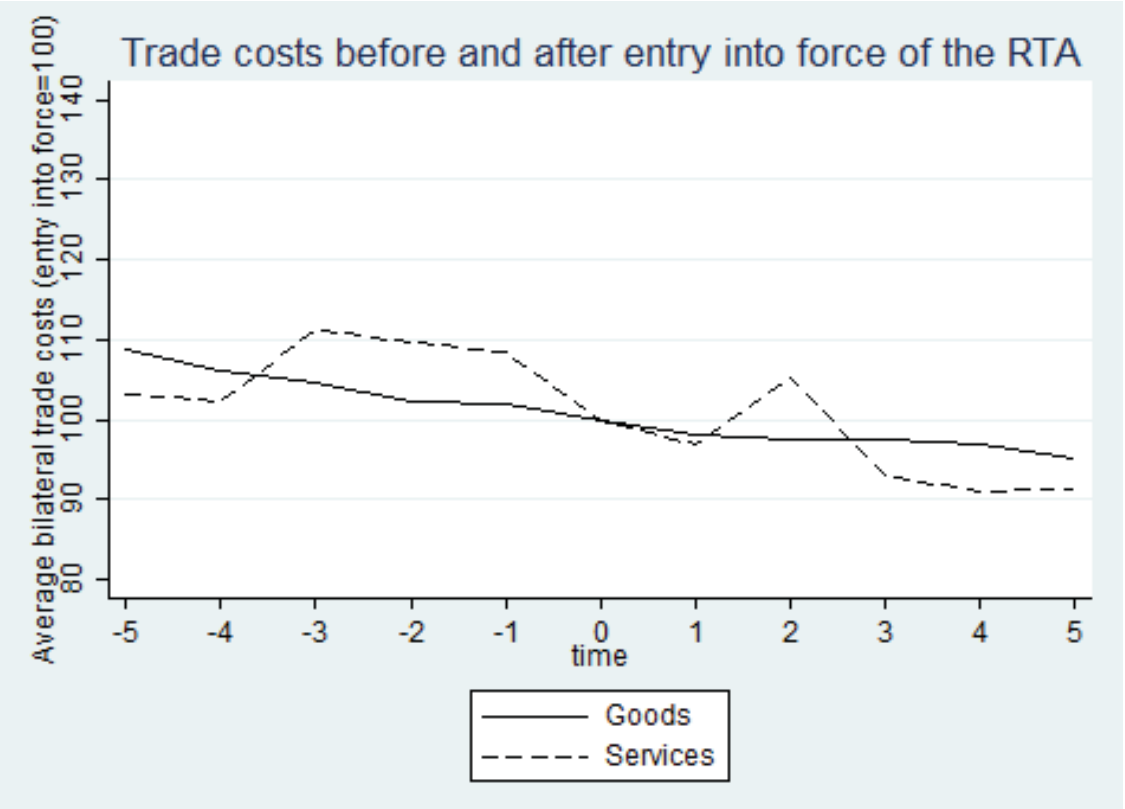

reason for focusing on the EU is first that EU countries have among themselves the deepest level of integration for services industries. There are more than $500 \mathrm{EC}$ regulations dealing with services in the EU, and the objective of creating an effective internal market in services has been a priority since the adoption of the Single Market Act in 1992 (Messerlin, 2012). Moreover, a large share of observations in our dataset correspond to EU countries and it is interesting to see how including or excluding EU countries in the analysis impacts results.

The surprise in Figure 4 is that after 2002, we measure higher trade costs among EU countries than in the RTAs signed by the EU or in other non-EU RTAs, alhtough there is some convergence towards the end of the sample period. We investigate in more detail in the next section what could drive these results, but Figure 4 is not at odds with the gravity literature that finds that an EU dummy variable generally has a negative sign (indicating that EU countries trade a lower volume of services than predicted by the gravity model). Whether or not one believes the data, there is the question of why services RTAs are not clearly associated with lower levels of trade costs. 
Figure 4: Trade costs within and outside RTAs: the case of the European Union

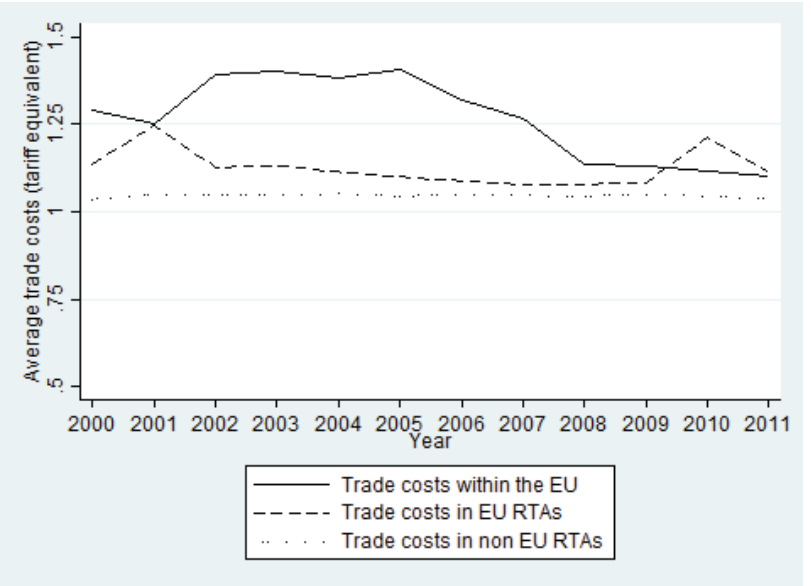

\section{Why are services trade costs not lower within regional trade agreements?}

\subsection{Can we trust the data?}

Anybody working in the area of services trade knows that cross-border trade statistics at a disaggregated level (by partner country and/or by industry) are problematic. To begin with, the coverage of balance of payments trade data is not comprehensive. While total trade in services is generally available for most economies, trade by partner country or by industry is missing for a significant number of reporters. In addition, for countries that do provide the disaggregated data, there is still a large share of unallocated trade (Miroudot and Lanz, 2008; Spinelli and Miroudot, 2015). For example, in the OECD TISP database, adding all the bilateral by industry data gives a figure that represents on average $70 \%$ of the total trade reported by countries. Almost one third of trade in services is not allocated to specific partners or industries.

In addition to unallocated trade, one can also question what the balance of payments precisely measures. With the development of the Internet and new technologies, many services transactions are difficult to account for. Measuring trade in services is more challenging than before and one should not underestimate the impact of these issues on the results of our study and any measure of 
trade costs based on actual trade data. But the quality of the data cannot explain by itself the trend observed over time as the there is no sign of a systematic bias that would minimize international trade in services over years only for countries within an RTA (and not for pairs of countries not belonging to any RTA). Issues related to statistics affect all economies within or outside RTAs. The only case where we should seriously investigate the role of statistical issues is the EU. Because of the European integration process, there is less information available on intra-EU trade, as opposed to extra-EU trade.

More important, it seems to us, is the question of whether covering only cross-border trade in services has an impact on our assessment of regionalism. Cross-border trade in services includes Mode 1 and to some extent Mode 2 and Mode 4 trade in services. But with some rare exceptions ${ }^{8}$, Mode 3 trade in services is not part of the cross-border trade statistics. To the extent that RTAs encourage Mode 3 over cross-border trade (in particular when they include an investment chapter that also liberalizes FDI), a substitution between cross-border trade and sales through commercial presence could explain why we do not see a significant impact of RTAs on cross-border trade costs. Unfortunately, data on sales of foreign affiliates (Foreign Affiliates Trade Statistics) are even less available than cross-border trade in services data. We can however apply a methodology similar to the one we apply to cross-border trade to measure the bilateral "investment costs" or more exactly the cost of selling through a foreign affiliate, the foreign affiliate sales (FAS) cost. Building on Head and Ries (2008), Gormsen (2011) has developed a measure of the cost of barriers to FDI. We can apply a similar methodology to sales of foreign affiliates, as the formula is at the end a derivation of the gravity equation and the gravity equation applies to FAS as well (see Bergstrand and Egger, 2007 and Kleinert and Toubal, 2010).

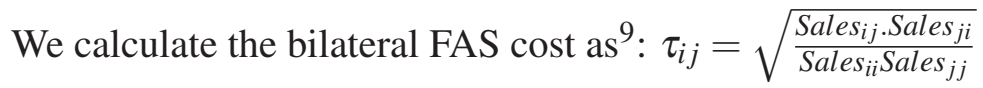

\footnotetext{
${ }^{8}$ For example, in the case of construction services, balance of payments data cover to some extent short-term contracts where there is commercial presence in the sense of GATS but no establishment (the foreign company operates in the territory of the partner country on the basis of a local office and remains a non-resident entity whose revenues are regarded as an international transaction recorded in the balance of payments). Construction services data sometimes include the cost of construction materials which are goods, another issue to measure accurately the services trade involved.

${ }^{9} \mathrm{We}$ do not discuss extensively the methodology as this is not the purpose of this paper to measure FAS costs.
} 
Figure 5: Foreign affiliate sales costs intra- and extra-EU (2001-2006)

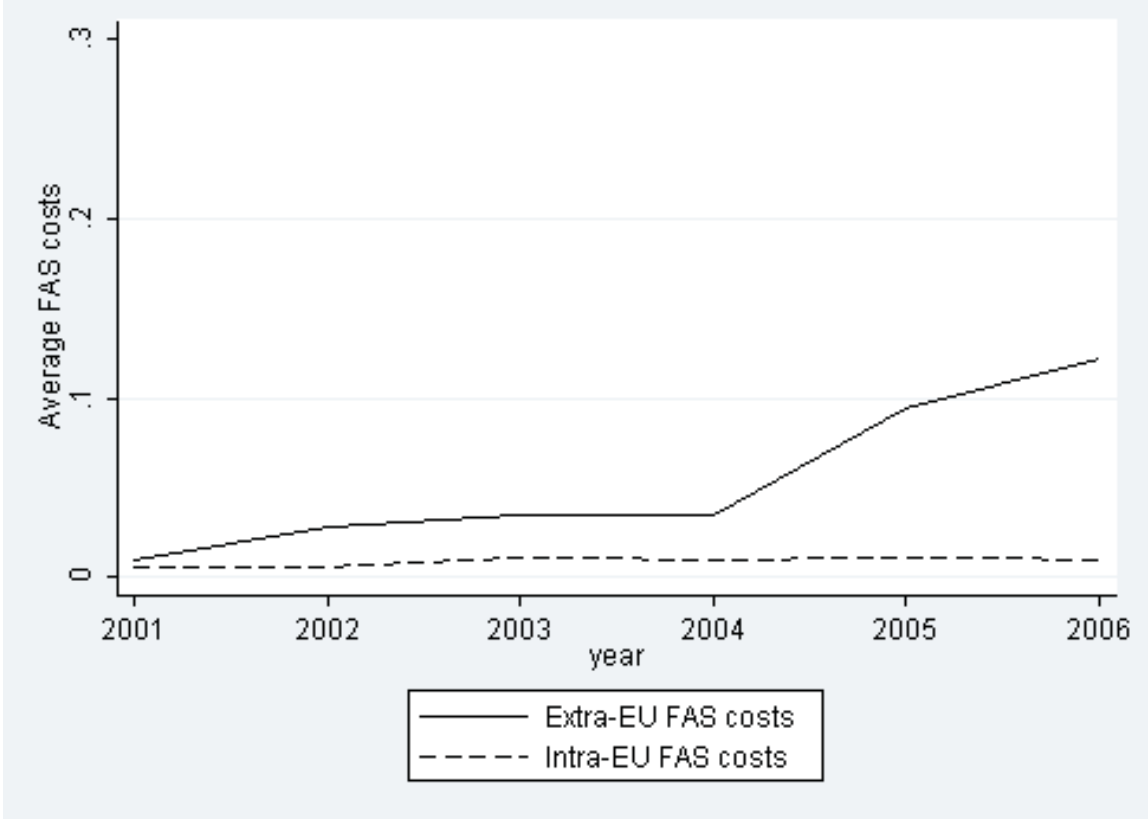

where sales from $i$ in $j$ and $j$ in $i$ are bilateral FAS, while the sales of $i$ in $i$ (and $j$ in $j$ ) are the domestic sales (calculated as the national turnover minus the sales of foreign affiliates). Due to constraints on the availability of such data, we calculate these bilateral FAS costs for 54 countries over the period 2001-2006. Figure 5 below presents the average FAS cost intra and extra-EU. Since there are very few non EU countries in the dataset, one should not over-interpret the results and generally speaking FAS statistics are quite fragmentary. But the point is that for EU countries for which we have relatively better FAS data, there is no indication that FAS costs have diminished within the EU in the first half of the 2000s. However, FAS costs are found to be lower within the EU and the discrepancy between intra- and extra-EU FAS costs increases over time. This increase is likely to reflect the availability of more data over time as because of the gaps in the data there are more and more non-EU pairs after 2004.

We can thus nuance the picture regarding the impact of RTAs. In the case of the EU, there seems to be an impact on the cost of providing services through Mode 3. But we have insufficient data Deriving the equation from a theory-consistent FAS gravity model, there should be a parameter similar to $\sigma$ in the Anderson and van Wincoop (2003) model or $\gamma$ in the Chaney (2008) model. We take here a very simple approach to compare FAS costs over time in the context of EU integration. 
to check whether this is specific to the EU and the deep integration achieved through the Single Market or whether a similar trend would be observed in all RTAs that cover Mode 3 or have a substantive investment chapter.

\subsection{Services reforms: do they benefit domestic and foreign producers in a similar way?}

In our analysis, we define trade costs as the additional costs faced by foreign suppliers as opposed to domestic producers. Equation 1 relates "domestic trade costs" to international trade costs. Because the measure is relative, a reform that would have the same (or a proportional) impact on domestic and foreign suppliers would not affect trade costs estimates. Another way of interpreting Figure 2 would then be that any services trade liberalisation (resulting or not from the signature of a RTA) lowers trade costs for all suppliers so that the ratio between foreign and domestic costs is not altered.

This would be the case first if RTAs had no impact on the actual trade regime. Schedules of commitments in services are legal bindings. Countries take market access and national treatment commitments but often these commitments just reflect the current state of regulations. Already at the multilateral level, the literature points out that countries have locked-in their current regime and not used GATS to liberalize trade (Hoekman, 1996; Adlung and Roy, 2005). It is even less likely that they would use RTAs to open up new services sectors. Reforming the telecoms sector or changing regulations for maritime transport will generally not be the outcome of a bilateral trade agreement. The political economy of services trade negotiations, involving a trade ministry which is generally not in a position to commit to reform key product markets, could explain why RTAs are about legal bindings and not actual trade reforms (VanGrasstek, 2010). Such bindings could nonetheless have a positive impact on trade by reducing the uncertainty around the trade regime and by bounding the level of restrictiveness the partner country could introduce in the future.

Then, another assumption is that when they do change the trade regime, RTAs have no impact 
on measures that discriminate against foreign suppliers. The concept of preferences is not easy to tackle in the context of services trade (Sauvé and Mattoo, 2011; Sauvé and Shingal, 2011). Some measures are not really prone to discrimination between domestic and foreign suppliers. For example, market regulations introducing rules on prices, access to networks or increasing the powers of a competition authority will equally benefit domestic and foreign services suppliers. It is not possible to create a market more competitive for domestic suppliers only or foreign suppliers would have to be totally excluded from this market. Then, there are measures such as licenses or taxes where it would be technically feasible to introduce discrimination between domestic and foreign producers but where in practice this is not the case. In the end, discriminatory measures are limited to foreign equity restrictions, labour market tests for the entry of natural persons, and the recognition of qualifications. But even in these areas, not all countries introduce discriminatory measures.

The trend in services reforms is also to increase competition, including by allowing foreign producers to enter the domestic market and compete. Countries that have reformed their telecoms or energy sectors, for example, have generally encouraged the entry of foreign firms to increase productivity and lower prices for consumers. In the presence of an incumbent firm previously benefiting from a domestic monopoly, foreign competition is important for the market to become competitive. Services reforms are generally not of a discriminatory nature and this gives less opportunities for negotiatiors of RTAs to offer genuine preferences to partner countries.

\subsection{Is services trade liberalisation de facto MFN?}

For the same reasons stated above, there is no clear evidence that discrimination among foreign producers is the objective or outcome of services RTAs. Unlike tariffs in the case of goods, there is no easy way to grant preferences for services providers of specific countries. Market access barriers or barriers to competition generally apply the same way to all foreign suppliers. In the case of the recognition of qualifications or visa policies, some advantage may be given to a priviledged partner 
country. For example, a mutual recognition agreement can be signed or a quota can be granted to temporary services providers of a given nationality. But in practice, there are very few instances where countries do discriminate.

Once again, one should keep in mind that services are generally regulated in domestic laws that are designed for domestic purposes by the ministries in charge of specific services sectors. Such laws are not used for commercial diplomacy and do not include legal instruments giving opportunities to trade negotiators to grant actual preferences to specific countries. This is why services RTAs are most of the time about "preferential bindings" rather than actual preferences.

Another reason is that rules of origin for services are quite liberal in the case of legal persons (Fink and Nikomborirak, 2007; Miroudot et al., 2010). GATS Article V:6 requires that foreign services suppliers established in a country and engaged in "susbtantive business operations" benefit from the treatment granted in RTAs signed by that country. For example, EU companies established in the US can benefit from NAFTA provisions and have the same treatment as US companies exporting services to Mexico or Canada. The "substantive business operations" criterion is generally not subject to specific tests or requirements. ${ }^{10}$ This could explain why countries are not willing to introduce discriminatory barriers to cross-border trade in services. Such barriers could be circumvented by the establishment of companies in countries that would have the most preferential treatment.

This being said, we observe in our dataset differences in trade costs according to the partner country. Figure 6 highlights differences based on the architecture of RTAs and the way of scheduling commitments. Trade costs tend to be lower between countries having signed a NAFTA-inspired $\mathrm{RTA}^{11}$ where there is a negative list of commitments and where services and investment (including investment in services) are dealt with in two separate chapters. GATS-inspired RTAs that follow the GATS approach for scheduling commitments (a positive list of sub-sectors where market access and national treatment commitments are made by mode of supply, followed by a list of limitations) have on average higher trade costs, even higher than for pairs of countries with no RTA.

\footnotetext{
${ }^{10}$ An exception is found in the agreements signed by China with Hong Kong and Macao (see Emch, 2006)

${ }^{11}$ See Houde et al. (2007) for a more detailed discussion of NAFTA-inspired versus GATS-inspired regional trade agreements.
} 
However, Figure 6 should not be interpreted as a causal relationship between the way of scheduling commitments and the level of trade costs. The results are essentially based on the composition of each group of countries whose trade costs are being measured. Trade costs are the lowest (at the end of the 2000-2011 period) in the group of "other RTAs" that includes economic integration agreements, such as the EC Treaty, the European Economic Area (EEA) agreement, the agreement of the European Free Trade Association (EFTA), or the Australia New Zealand Closer Economic Partnership Trade Agreement (ANZCEPTA). By definition, countries parties to these agreements are geographically and culturally closer, hence their lower bilateral trade costs. NAFTA-inspired agreements were originally signed between close countries (initially Canada, Mexico, and the United States) and over the period trade costs are found to be higher when the NAFTA template is used by other countries. GATS-inspired agreements include many North-South and South-South RTAs signed between countries geographically and/or culturally more distant and where services trade is less developed.

Figure 6: Trade costs by type of scheduling (2000-2011)

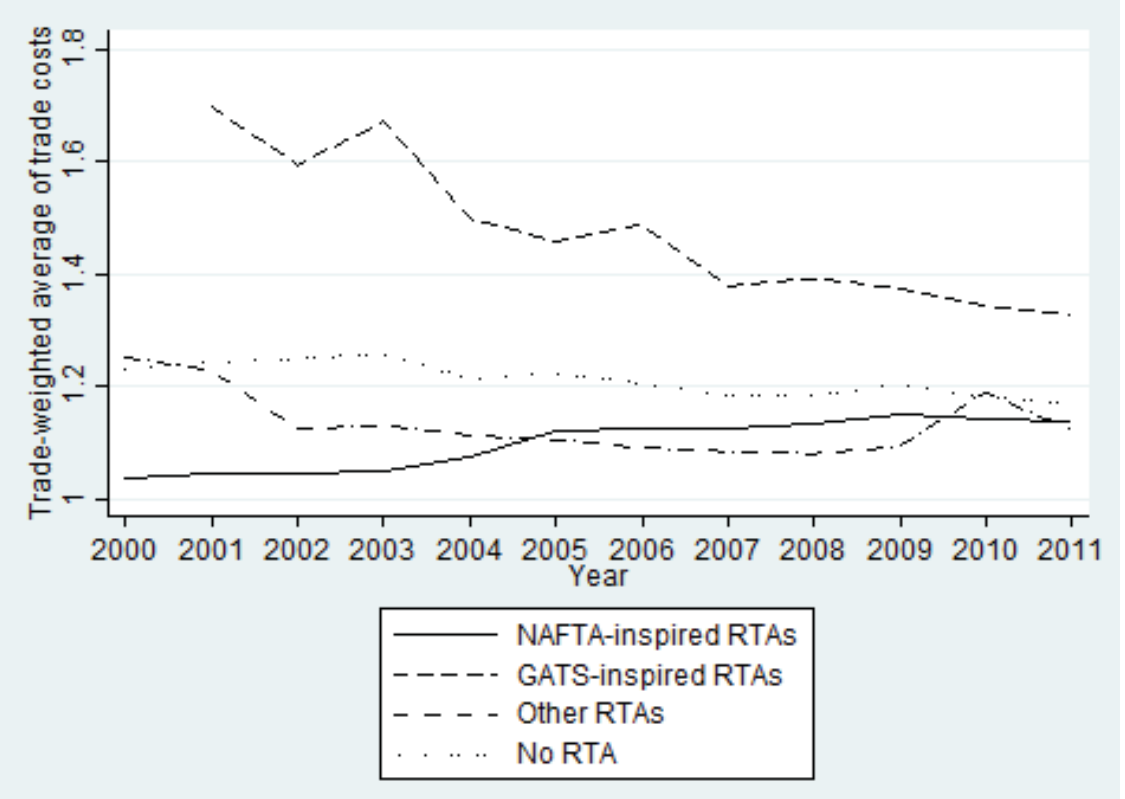




\section{Conclusion}

This chapter has addressed the question of whether services RTAs have an impact on bilateral trade costs. In the case of services, there is no clear evidence that trade costs are much lower within RTAs than outside. This is not a surprising result when one looks more closely at how services trade liberalisation takes place and what the role of services chapters in RTAs is. Services agreements are about preferential bindings and generally do not introduce actual discrimination that would favour services suppliers from the parties to the agreement. As such, services RTAs are to some extent paradoxical. They signal a preference for specific partner countries but they do not provide them with preferential treatment, unlike what can be observed with goods. From an economic perspective, this is all the better as preferences lead to trade distortions.

Do our results mean that RTAs have no economic impact and do not affect trade costs? Further research on this question is required, including the specification of a full econometric model explaining trade costs in terms of observables, including membership of an RTA. Preliminary findings based on graphical analysis and descriptive statistics suggest, however, that RTAs might lower trade costs, although not to a striking degree, but the costs are decreased not only for the parties to the agreement but also for non-parties. This could be explained by the liberal rules of origin that extend the benefits of market access and national treatment commitments beyond parties, or more simply by the unilateral and de facto MFN nature of services trade liberalisation. Most reforms in services sectors are driven by domestic concerns and adopted independently of any trade negotiation. RTAs bind these reforms and their provisions reflect the more recent state of the law and new regimes that are more favourable for foreign suppliers. Our results are consistent with such an interpretation of services RTAs. 


\section{References}

Adlung, R., Miroudot, S., 2012. Poison in the wine? Tracing GATS-minus commitments in regional trade agreements. Journal of World Trade 46 (5), 1045-1082.

Adlung, R., Roy, M., 2005. Turning hills into mountains? Current commitments under the General Agreement on Trade in Services and prospects for change. Journal of World Trade 39 (6), 11611194.

Anderson, J. E., van Wincoop, E., 2003. Gravity with gravitas: A solution to the border puzzle. American Economic Review 93 (1), 170-192.

Bergstrand, J., Egger, P., 2007. A knowledge-and-physical-capital model of international trade flows, foreign direct investment, and multinational enterprises. Journal of International Economics 73 (2), 278-308.

Chaney, T., 2008. Distorted gravity: The intensive and extensive margins of international trade. American Economic Review 98 (4), 1707-21.

Chauffour, J.-P., Maur, J.-C. (Eds.), 2011. Preferential trade agreement policies for development. A handbook. The World Bank.

Eaton, J., Kortum, S., 2002. Technology, geography, and trade. Econometrica 70 (5), 1741-1779.

Emch, A., 2006. Services regionalism in the WTO: China's trade agreements with hong kong and macao in light of Article V(6) of GATS. Legal Issues of Economic Integration 33, 351-378.

Fink, C., Molinuevo, M., 2008. East asian preferential trade agreements in services: liberalisation content and wto rules. World Trade Review 7 (4), 641-673.

Fink, C., Nikomborirak, D., 2007. Rules of origin in services: a case study of five asean countries. Policy Research Working Paper 4130, The World Bank. 
Gormsen, C., January 2011. The declining barriers to foreign direct investment and how to see them, mimeo.

Head, K., Ries, J., 2001. Increasing returns versus national product differentiation as an explanation for the pattern of u.s.-canada trade. American Economic Review 91 (4), 858-876.

Head, K., Ries, J., 2008. FDI as an outcome of the market for corporate control: Theory and evidence. Journal of International Economics 74 (1), 2-20.

Hoekman, B., 1996. Assessing the general agreement on trade in services. In: Martin, W., Winters, L. A. (Eds.), The Uruguay Round and the developing countries. Cambridge University Press, pp. $88-124$.

Houde, M.-F., Kolse-Patil, A., Miroudot, S., 2007. The interaction between investment and services chapters in selected regional trade agreements. OECD Trade Policy Working Paper 55, OECD Publishing.

Kleinert, J., Toubal, F., 2010. Gravity for fdi. Review of International Economics 18 (1), 1-13.

Marchetti, J. A., Roy, M., 2008. Services liberalization in the WTO and in PTAs. In: Marchetti, J. A., Roy, M. (Eds.), Opening Markets for Trade in Services. Countries and Sectors in Bilateral and WTO Negotiations. Cambridge University Press, pp. 61-112.

Messerlin, P. A., 2012. The european community trade policy. In: Kreinin, M. E., Plummer, M. G. (Eds.), The Oxford Handbook of International commercial policy. Oxford University Press.

Miroudot, S., Lanz, R., 2008. Measuring bilateral trade in services: A note on the data collected and estimated for the services trade restrictiveness index. Tech. Rep. TAD/TC/SXM(2008)2, OECD.

Miroudot, S., Sauvage, J., Shepherd, B., 2012. Trade costs and productivity in services sectors. Economics Letters 114 (1), 36-38. 
Miroudot, S., Sauvage, J., Sudreau, M., 2010. Multilateralising regionalism: how preferential are services commitments in regional trade agreements? OECD Trade Policy Working Paper 106, OECD Publishing.

Novy, D., 2011. Gravity redux: Measuring international trade costs with panel data. CESifo Working Paper Series 3616, CESifo Group Munich.

Pomfret, R., Sourdin, P., 2009. Have asian trade agreements reduced trade costs? Journal of Asian Economics 20 (3), 255-268.

Sauvé, P., Mattoo, A., 2011. Services. In: Chauffour, J.-P., Maur, J.-C. (Eds.), Preferential trade agreement policies for development. A handbook. The World Bank, pp. 235-274.

Sauvé, P., Shingal, A., 2011. Reflections on the preferential liberalization of services trade. Journal of World Trade 45 (5), 953-963.

Spinelli, F., Miroudot, S., Ocotber 2015. Estimating bilateral trade in services by industry - the ebtsi data set. Tech. rep., OECD.

VanGrasstek, C., 2010. The political economy of services in regional trade agreements. OECD Trade Policy Working Paper 112, OECD Publishing.

Walsh, K., 2006. Trade in services: Does gravity hold? a gravity model approach to estimating barriers to services trade. Discussion Paper Series 183, Institute for International Integration Studies.

WTO, 2011. The WTO and preferential trade agreements: From co-existence to coherence. World Trade report 2011, World Trade Organization. 


\section{Annex 1 - List of services agreements covered in the dataset}

ASEAN-Australia-New Zealand FTA
ASEAN-China FTA
ASEAN-Korea FTA
Australia-Chile FTA
Australia-New Zealand CER
CAFTA-DR
Canada-Chile FTA
Canada-Peru FTA
Chile-Colombia FTA
Chile-Costa Rica FTA
Chile-EI Salvador FTA
Chile-Mexico FTA
China-Chile FTA
China-New Zealand FTA
China-Pakistan FTA
China-Peru FTA
China-Singapore FTA
Costa Rica-Mexico FTA
EEA
EFTA-Chile FTA
EFTA-Korea FTA
EFTA-Mexico FTA

EFTA-Singapore FTA

El Salvador-Mexico FTA

EU-Albania SAA

EU-CARIFORUM States EPA

EU-Chile AA

EU-Croatia SAA

EU-FYROM SAA

EU-Korea FTA

EU-Mexico EPA

EU-Montenegro SAA

Guatemala-Mexico FTA

Honduras-Mexico FTA

India-Korea CEPA

India-Singapore CECA

Japan-Brunei Darussalam EPA

Japan-Chile EPA

Japan-Indonesia EPA

Japan-Malaysia EPA

Japan-Mexico EPA

Japan-Philippines EPA

Japan-Singapore EPA

Japan-Switzerland EPA

\author{
Japan-Thailand EPA \\ Japan-Viet Nam EPA \\ Korea-Chile FTA \\ Korea-Singapore FTA \\ Mainland and Hong Kong CEPA \\ Mainland and Macao CEPA \\ Mexico-Nicaragua FTA \\ NAFTA \\ New Zealand-Hong Kong, China CEP \\ New Zealand-Singapore CEP \\ Panama-Chile FTA \\ Singapore-Australia FTA \\ Thailand-Australia FTA \\ Trans-Pacific SEP \\ US-Australia FTA \\ US-Bahrain FTA \\ US-Chile FTA \\ US-Jordan FTA \\ US-Morocco FTA \\ US-Oman FTA \\ US-Peru TPA \\ US-Singapore FTA
}

